Review article accepted for publication at Aggression and Violent Behavior

DOI: 10.1016/j.avb.2015.07.009

\title{
Sexualized war violence. Knowledge construction and knowledge gaps
}

\begin{abstract}
This qualitative literature review provides an overview of the proliferating research field that research on sexualized war violence has become. The article critically reviews some of the main theories on sexualized war violence in light of five basic and interrelated dimensions: terminology and conceptualizations, etiological approaches, disciplinary grounding, contextual emphasis, and, lastly, the policy implications these dimensions imply. The review involves a discussion of critical contestations within the field and an outline of research gaps that still need exploration. Sexualized war violence is a research area that warrants criminological attention; it is an aim of this article to suggest possible theoretical and empirical directions that such inquiries may take.
\end{abstract}

Key words: sexual/ized war violence, war rape, mass atrocities, perpetrators, supranational criminology 


\section{Introduction}

Only a few decades ago, sexualized war violence was underreported and under analyzed. It was considered an inevitable consequence of warfare, and thus irrelevant for analyses of war and international politics. Today, sexualized war violence is a vast and growing field of research, involving multiple disciplines. It is also an increasingly important concern for international security politics (e.g., Kerry \& Hague, 2014). From a marginalized position in the wider fields of research on peace, conflict, and international relations, sexualized war violence is today seen as an indispensable part of academic presentations and analyses of war and peace processes. Taking the increased criminological attention to international crimes into account, the purpose of this article is twofold: (1) to critically structure and assess the status of research on sexual war violence to better understand how we theorize the phenomena that this term captures; (2) to introduce this particular area of atrocity crimes research to internationally oriented criminologists and scholars from adjacent fields. Although it is not within the scope of this article to conduct empirical analysis, it can be read as an invitation to further criminological inquiry into both the theoretical and empirical phenomena that sexualized war violence comprise.

As a brief outline of the pages to come, I will start by locating research on sexualized war violence within the emerging subfield of criminology referred to as supranational or international criminology. I will then review main theorizations on sexualized war violence in light of five basic and interrelated dimensions: terminology and conceptualizations, etiological approaches, disciplinary grounding, contextual emphasis, and, lastly, the policy implications that a given research agenda implies or suggests. This review aims to provide the reader with an overview of the field, a discussion of critical contestations therein and an outline of research gaps that still needs exploration.

\subsection{Locating sexual war violence research within a criminological tradition}

Over the last decade, supranational and international criminology research that focus on atrocity crimes $^{1}$ and international criminal prosecution is emerging as a criminological

\footnotetext{
1 “Atrocity crimes” here refers to violence that falls under the umbrella of core crimes under international law: war crimes, genocide and crimes against humanity (see Scheffer 2006).
} 
subfield in its own right (e.g., Hagan et al., 2005; Karstedt, 2012; Maier-Katkin et al., 2009; Smeulers \& Haveman, 2008; Smeulers \& Grünfeld, 2011). Despite this increased criminological focus on international conflict related crimes, sexualized war violence is only to a limited extent addressed in these efforts. In general, criminological studies of mass violence in conflict situations do not analytically differentiate between the repertoires of violence that may constitute the aggregated crime they address. When sexualized war violence is included in criminological research on war crimes, authors tend not to draw on the established research field that sexualized war violence research has become. These criminological inquiries tend not to explain the explicit sexualized expression of the violence or incorporate a gender perspective to understand sexualized war violence as such (for noticeable exceptions, see Ericsson, 2011; Mullins, 2009a), or war crimes more generally (Smeulers \& Hoex, 2010). On the other hand, research on sexualized war violence is delimitated by a thematic focus across several disciplines ${ }^{2}-$ but tends not to draw on criminological thinking on crime, engagement in criminal behavior, and crime control in its attempt to understand and analyze the causes and consequences of this particular form of war violence. Sexualized war violence research tends to focus exclusively on this particular form of violence and primarily, often unilaterally, analyze it from a gendered perspective. Hence, the fields of international/supranational criminology on one hand and sexualized war violence research on the other constitute and develop as separate scholarships. I hold that a combination of perspectives, and a scholarly interaction and debate between these two fields, offer both with a potential for mutual benefits and an increased understanding of the social phenomena in question (Houge, 2014). The expanding national and universal criminalization of sexual war violence offenses make this research field particularly relevant for criminological inquiry, based on the discipline's tradition of critical studies of criminalization processes, control measures, related correctional and social services, as well as its focus on victimology. The potential of a criminological gender research focus on atrocity crimes generally and sexual war violence more specifically can add to our current understanding of the phenomena under study, the legal strategies applied in this particular field, and critically

\footnotetext{
${ }^{22}$ As a cross-disciplinary field of research sexual war violence research used to be dominated by gender researchers, but is currently dominated by political scientists. See section on Ideological and disciplinary grounding below.
} 
assess perpetrator- and victim constructions, perspectives and re-presentations, in the legal system, in the overall public on local, national and international levels, and, not least, in scholarly publications on this thematic (Houge et al., 2015).

\section{Theorizations on sexualized war violence}

Theories on sexualized war violence differ in terms of chosen terminology and conceptualizations, etiological weighting, ideological grounding, contextual emphasis, and the policy implications that different theorizations ask for. The continuums of perspectives that each of these dimensions encompass reflect both the accumulation of knowledge that research build on through time and different epistemological horizons or political choices researchers make as they enter and navigate this field.

While this review provides a general overview, it cannot capture all there is to say about research on sexual war violence, or all that we know and have learned about the phenomena under study ${ }^{3,4}$. Some of the texts I refer to are included because they are groundbreaking, innovative or central in their contribution, while others are included because they illustrate trends and directions I wish to draw attention to. Combined, these publications reflect central theoretical differences and emphasize the influence of different methodological and theoretical choices in the research process for the outcome and applicability of research.

\footnotetext{
${ }^{3}$ In particular, I do not include research contributions that focus on the medical, material and psychosocial needs of and short term and long term consequences for victims in the aftermath of war (Bosmans, 2007; de Brouwer and Ka Hon Chu 2009; Henry, 2010; Kaitesi, 2014; Kuwert et al., 2010; Milillo, 2006; Rubio-Marín, 2012; Skjelsbæk, 2012; Vranic, 1996). Nor do I address the situation of children born from wartime rape, which has received only limited attention by a few scholars - and comprise and important gap to explore in future research (see Carpenter, 2007; 2010).

${ }^{4}$ For readers interested in prevalence and statistics Cohen and Nordås (2014) provide the most thorough examination of prevalence of sexual violence during conflict (covering all conflicts in the period 1989-2009). Their article is based on the Sexual Violence in Armed Conflict dataset, available at http://www.sexualviolencedata.org (Cohen and Nordås, n.a.). Also, the UN Secretary General publishes annual reports on sexual violence in armed conflict. (see UNSC S/2014/181 for the latest report)
} 


\subsection{Terminology and conceptualization: From implicit vaginal rape to differentiated sexual/ized ${ }^{5}$ violence}

Sexual war violence research has typically been led by feminist researchers working on women's issues with a primary focus on women as the silenced victims of men's violence. In much of this writing on sexualized war violence, sexual violence as a term has been used interchangeably with rape. Rape, in turn, has implied vaginal rape, although it has not always been explicitly defined as such. Susan Brownmiller (1975), who is often credited for putting wartime sexual violence on both the feminist movement agenda and the overall research agenda with her ground-breaking book Against our will, is a case in point. She held that a victim of war rape "is chosen not because she is representative of the enemy, but precisely because she is a woman, and therefore an enemy”(1975: 62, emphasis in original). Similarly, in a much-cited and more recent article on “soldier-rapists,” Lisa Price (2001: 214) contends that "[a]s in peacetime, rape in war is a gender-specific act, an expression of hatred of women qua women.” Quoting Tompkins, Price continues by asserting that “[r]ape is (...) a one-way street where the risk factor is being female.” In researchers' and activists' attempts at forcing much-needed attention to women's war experiences in international relations thinking and policy making, some have - in terms of sexual war violence - advocated not a gender perspective, but a de facto gender exclusive perspective.

\footnotetext{
${ }^{5}$ I deliberately use "sexual violence” and "sexualized violence” interchangeably in this text. There is a tendency among both activists and scholars in this field to categorically claim that sexual violence in war is never about sex, but about power, terror and control (e.g., Jolie 2014; Kuehnast 2014). Although this can be true on a structural, macro level, it need not be the case on the micro level at which individual perpetrators act. By using the term "sexual violence", I intend to not underestimate the materiality of the violence as sexual, that is, the sexual intent, lust or desire that individual perpetrators might experience. By also applying "sexualized violence”, the intention is to highlight that the offenses included might first and foremost be acts of violence or (violent) power, and that the sexualized expression of the violence is intended to serve an instrumental purpose beyond satisfying sexual desire, such as instigating humiliation or fear upon the victims and victims' communities.
} 
Sexual war violence has been conceptualized as a war against women that only patriarchy and misogyny can explain (e.g., Stiglmayer, 1994a). An effect of these successful efforts at making many women's war experiences visible is that scholars have simultaneously been blind to or even contributed to the definitional silencing of male victims of similar violence. The term "sexual violence" is so strongly associated with women victims, and male perpetrators, that applying gender lenses in analysis often is understood as focusing on female victims, to the extent that it has left limited definitional or conceptual place or attention for (heterosexual) male victims of sexual violence (e.g., Cockburn, 2011: 191). This is changing as more scholars recognize that men, too, are subjected to sexual violence during wars and conflicts. The prosecutions of sexual war violence at the international ad hoc criminal tribunals following the wars in the former Yugoslavia, Sierra Leone, and the genocide in Rwanda, as well as at the International Criminal Court (ICC), correspond to this development and provide detailed documentation and information from testimonies about sexual war violence directed at both men and women. Scholars have still just begun to explore this documentation (see de Brouwer, 2005; Houge, 2014; Mullins, 2009b; Oosterveld, 2011). Noticeably, the definitions of rape and sexual violence in the Rome Statute have become guiding for many scholars both within and outside the legal discourse to define the scope of offenses they include in their inquiries, and are worth quoting also here. According to the Amended Elements of Crime of the Rome Statute, "sexual violence" is an umbrella term that refers to a wide repertoire of violence, including rape, but also "sexual slavery, enforced prostitution, forced pregnancy, enforced sterilization, or any other form of sexual violence of comparable gravity”. Breaking it down to its constituents, the definition of rape includes as a key element that

[t]he perpetrator invaded the body of a person by ... penetration, however slight, of any part of the body of the victim or the perpetrator with a sexual organ or of the anal or genital opening of the victim with any object or any other part of the body (ICC, 2011).

These definitions do not preclude either male victims or female perpetrators, and were specifically included for that purpose (Oosterveld, 2011: 59, fn 68). Yet, in media, among NGOs, human rights organizations, policymakers, and scholars, it is oftentimes argued that as women and girls comprise the vast majority of victims or are disproportionately affected, they 
are the ones who should be warranted resources and attention (e.g., de Brouwer, 2005: 26). Grey and Shepherd (2013) show how most publications and documents only include a comment or footnote in which they recognize that male victims exist, before the attention is shifted fully to female victims (see also Henry et al., 2004; Houge, 2008; Zarkov, 2001 for criticisms of the overall presumption of female victims). As several scholars have already commented, the vast majority-argument is, at best, an educated guess, as surveys have tended not to include men as potential victims or a gender sensitive, differentiated description of the offenses that they intend to map (Grey and Shepherd, 2013). Also, the stigma associated with being a victim of sexualized violence is likely to often be higher for many male victims than for many women, thus dark figures are probably underestimated among this group.

Importantly, even though it is likely that there is a majority of female victims(Cohen et al., 2013), that does not make the minority of male victims less worthy victims, or an insignificant, irrelevant or less important a group to focus on, not academically, politically, or socially (e.g., Houge, 2014; Jones, 2006; Sivakumaran, 2007; Zarkov, 2001). This recognition calls for a greater level of accuracy and precise use of terminology in publications on sexualized war violence. If the focus is exclusively on women, that legitimate limitation should be clearly defined and not taken for granted. If the focus is on vaginal and anal rape, but not other forms of sexual threats and abuse, that should be stated explicitly. If the focus is on the aggregated term sexualized war violence, both scholars and readers should be aware that different forms of sexual violence might be associated with differentiated motivations and consequences. Importantly, this is also the case within specific categories of sexual violence forms.

When writing and reading about sexual war violence, and in particular with regards to statistics and prevalence estimates, it is furthermore necessary to clarify beyond the description of the acts themselves. For example, is it sexual war violence or conflict-related sexual violence when the victims are not civilians, when the perpetrators are not members of armed groups, when the violence is committed in post conflict society, when soldiers rape their wives or partners, or when soldiers rape off duty or rape their peers? Sexual war violence has different connotations in different times and places, and likely also different explanations - and it is a challenge of most surveys, and perhaps also most studies, that these factors are not clearly defined. Also, we do not know if the increased level of reporting 
correlates with increased levels of sexual violence, or to what extent or where that correlation may be real. Both cultural and linguistic sensitivity and concrete terminology is important if we wish to unveil the extent and experience of sexual war violence, not least as these are experiences often concealed with metaphors and by shame (see also Peterman et al., 2011).

\subsection{Etiological approaches: From biologically determined to socially constructed perpetrators}

Related to the invisibility of male victims in most accounts on sexual war violence, is neglect towards perpetrators, and in particular principal or direct perpetrators. The (female) victimoriented focus of most research outlined above, important as it is, has also produced a research field where most theorizations about perpetrators and etiology are based on assumptions derived from female victims' accounts. Often highlighted as a particularly important lacuna in current research (e.g., Henry et al., 2004; Skjelsbæk, 2010), I will pay special attention to and elaborate on the presentations of principal perpetrators here. As stated by Isikozlu and Millard (2010),

it is assumed that the result of rape - for example, the breakdown of families, HIV/AIDS, or pregnancy - is the reason for its perpetration. Also, the perceptions of individuals raped as to why they were raped are often assumed to be the same as the motivations of the perpetrators, which may or may not be true.

Historically, the lack of perpetrator focus can be ascribed to the overall neglect of sexual war violence in scholarly publications and legal reactions. Wartime rape and sexual violence has traditionally been considered war booty, an inevitable consequence of warfare and simplistically explained by reference to the saying "boys will be boys" (Seifert, 1994; Wood, 2009). As research on sexualized war violence and its consequences has expanded, the still limited focus on perpetrators can partly be explained by a deliberate choice to focus exclusively on the hitherto silenced victims, and partly by a lack of will to understand and consider perpetrators subjects that could or should be given any opportunity to legitimize, justify or explain their offenses and actions. However, there are some scholars that have engaged in this field specifically (Baaz \& Stern, 2009; Cohen, 2013; Henry et al., 2004; Leiby, 2009; Lilly, 2007; Price, 2001; Stiglmayer, 1994b; Weaver, 2010), and many more in the field of atrocity crimes research more broadly, with a primary focus on perpetrators (e.g., 
Brown, 2014; Dawes, 2013; Fujii, 2009; Kelman \& Hamilton, 1989; Smeulers, 2008; Straus, 2006; Tanter et al., 2006; Vetlesen, 2005; Zimbardo, 2008).

This research sheds light on some processes that might help increase our understanding of atrocity crimes, and so-called excessive violence more specifically. An apparent common denominator of many excessive acts of violence in conflict and war situations, both sexualized violence and non-sexualized violence, is that it is committed by groups and that group violence tends to be more extreme in form (e.g., Smeulers, 2008). Several group rapes in the documentation from Bosnia illustrate how the rapes became more and more physically violent, that is, beyond the rape itself, the larger the number of perpetrators participating, implying a violence spiral, where the victim appears to be a tool upon which perpetrators compete to demonstrate an extreme form of violent masculinity vis-à-vis peers. This requires a competitive environment, dehumanization processes aimed at the victim and his or her group, and direct or implied peer pressure (Houge, 2014). Studies of war crimes and social psychological experiments suggest that we should not underestimate human capability and willingness to act out of fear of not conforming to the standards, actions or norms of the group to which one belongs or wishes to be part of (Grossman, 2009; Zimbardo, 2008). Violence seems often also to be instigated by one or two leader type members of the group (Smeulers, 2008). American veterans from the Vietnam War have testified how they were both carried away and did not want to stand out in comparison with peers (Weaver, 2010; Vietnam Veterans Against the War, 1971). David Grossman (2009), who has researched how and why soldiers kill, concludes that it is not the individual soldiers who kill, but the primary group or combat unit of which they are members. His findings suggest that the group becomes such a strong unit that its members do not consider themselves as individually responsible for their acts - guilt is rather allocated to the group.

Cohen (2013) further finds that an armed group's recruitment practice can help explain the use of excessive violence, in a complex regression analysis of global conflict violence data. She exposes that the degree of forced recruitment is significant for the likelihood that the armed group will engage in sexual violence. According to her combatant socialization theory, soldiers are more likely to engage in aggressive and costly behavior the lower the social cohesion of the group is. In such groups, excessive and/or sexual violence becomes a tool through which the group binds its unwilling members together. The argument is that if they 
have participated in violence that is beyond any acceptable or even comprehensible or justifiable level, so far from societal norms that it becomes difficult or impossible to return, the group creates a sense of social cohesion, an experience that unites the members and cut ties with outside communities. These studies both add to and challenge the early and narrower causal explanations rooted in patriarchy theory as introduced in section 2.1.

In a limited study of established perpetrators of sexual violence from the wars in Bosnia, based on an analysis of court transcripts from the International Criminal Tribunal of the former Yugoslavia, I found five overarching idealized explanations for participation in sexual violence: competition, which refers to explanations that emphasize sexual violence as a tool for competitive purposes, for perpetrators to demonstrate an extreme form of virility or masculinity vis-à-vis peers or vis-à-vis the victim and the victim's group; conformity, which underline how some perpetrators participated in sexual violence because they did not dare to confront or behave differently than the group of which they were members; opportunism, understood as the opportunity war provided for some to rape or sexually abuse ${ }^{6}$; idealism, where sexual violence is a means to a goal - the goal being either political or "simple" soldier idealism, that is, ideals about how soldiers ought to behave, where orders and obedience come to play; and survival, referring to perpetrators who feared that they would be killed themselves unless they lived up the demands or expectations of the group and participated in the violence. These categories are not mutually exclusive or exhaustive beyond the limited empirical material studied. Their transferability to other tribunals, conflicts and perpetrators remains to be tested (Houge, 2009; 2014).

The following is an attempt to categorize research on sexual war violence according to the approaches to individual perpetrators that different publications apply. In an admittedly simplified account, the dominant narratives on perpetrators of sexual war violence range from i) a story about sex, via ii) a story about a few rotten apples, to iii) a story about the rotten barrel. In short, the story about sex - as opposed to gender - emphasizes what men - qua men - are biologically and physically capable of, and to a varying extent, genetically inclined to do

\footnotetext{
${ }^{6}$ Note that this does not necessarily suggest a pre-war inherent characteristic of the perpetrator. War can construct the ability and will to rape through, e.g., widespread and institutionalized dehumanization, misogyny, heterosexism and/or xenophobia.
} 
when war offers the opportunities. This narrative is advocated by socio-biologists (Gottschall, 2004; Miller, 2014). The story about a few rotten apples is a story that emphasizes deviant behavior and pathologic explanations grounded (with)in individual perpetrators. This was the official story about the war crimes committed in the notorious Abu Ghraib detention center in Iraq (e.g., Brigadier General Kimmitt, quoted in Leung, 2004). It is perhaps particularly prevalent in the face of female principle perpetrators or superiors (see Sjoberg, 2007, for an analysis of the gendered othering of female combatants in general, and female perpetrators in particular in relation to the war in Iraq). This explanation has been criticized for using the convicted perpetrators as scapegoats to hide or reduce institutionalized responsibility (Caldwell, 2012; Zimbardo, 2008). This criticism again enacts the third narrative, the story of the rotten barrel ${ }^{7}$, the barrel being either the armed group, the military or society at large. According to this narrative, it is the barrel that produces conditions that may contaminate its members and construct perpetrators. This approach is advocated in various forms by social constructivist scholars and is, by far, the understanding that has the most proponents in the scholarly community ${ }^{8}$. According to variants of this explanation, perpetrators are ordinary men (and women, although this is rarely addressed) that are subjected to and actively participate in cultural, social and structural processes that allow for and trigger sexual violence (Cockburn, 2011; Skjelsbæk, 2001). In most explanations, militarized masculinity

\footnotetext{
${ }^{7}$ The rotten apple/barrel analogy is based on Phillip Zimbardo’s (2008:324-379) analysis of the torture at Abu Ghraib in 2003. Although his analysis is not pertaining to the acts that were sexual or sexualized per se, or the causes of that sexualization of violence, the analogy is nevertheless applicable.

${ }^{8}$ Classic social psychological experiments on conformity, peer pressure and obedience are often argued to support these explanations, although they do not address sexual violence as such. See, in particular, Philip Zimbardo’s 1971 Stanford Prison Experiment as described in Zimbardo (2008) and Stanley Milgram’s 1961 Obedience to authority-experiment in Milgram (1974). Asch’s 1951 conformity experiments might also add insights. Grossman (2009), in his analysis of US soldiers willingness to kill, finds peer pressure and group solidarity to be among the most crucial factors for a soldier's willingness or preparedness to kill. For an introduction to these works, see Smeulers (2011a; b).
} 
norms - i.e. gender constructs and expectations - play a crucial part (see, e.g., Baaz \& Stern, 2009; Skjelsbæk, 2001) ${ }^{9}$.

Variants of the story about sex are most often criticized for presenting sexual war violence as inevitable, for being deterministic and unable to account for the variation with which sexual violence is committed at different times, by different actors and in different conflicts, and for failing to explain female perpetrators and male victims in its emphasis of males' genetic and hormonal makeup (e.g., Dutton, 2007; Skjelsbæk, 2001). Narratives that focus on the rotten apples fail to explain the sheer number of perpetrators of sexual violence in many conflicts, which strongly suggests that all perpetrators cannot be pathologic or predetermined rapists or perpetrators of sexual violence. Similarly, studies that focus on war criminals and direct perpetrators of non-sexual mass violence during war and conflict situations find that perpetrators (as a group) cannot be depreciated as psychopaths, sadists, or mentally deficient - as inherently evil or predisposed to commit atrocious crimes (Smeulers, 2008). When sexual war violence is committed en masse, either as part of institutional practice or as part of a deliberate, targeted military strategy, not participating in sexual violence might be the deviant choice of action, whereas committing the offenses represents the norm (Drumbl, 2000) Accordingly, Cockburn (2011) holds that most perpetrators of sexual war violence are ordinary men under extraordinary circumstances. Narratives on the rotten barrel are primarily criticized for not taking sexual desire or biology into account at all, for turning a blind eye to the materiality of offences and the motives and experienced reality of actual offenders (e.g., Dutton, 2007; Gottschall, 2004). Furthermore, in its focus on the barrel, or even the apple orchard, this narrative cannot explain why so many, perhaps most, soldiers subjected to similar institutional and social pressures as those who become perpetrators, do not engage in sexual war violence, even in conflicts where these forms of violence are widespread and condoned (see also Wood, 2009).

In general, the nature vs. nurture debate often takes the form of straw man argumentation. Many scholars deny the possibility that sexual violence may at all be about sex for the perpetrator (Gertjejanssen, 2004; Gottschall, 2004; Kuehnast, 2014). Gottschall (2004), on

\footnotetext{
${ }^{9}$ Henry et al. (2004) suggest a multifactorial model of wartime rape that purports to include contributions from all three narratives in one explanatory framework, which is yet to be explored empirically.
} 
his part, dismisses social, cultural, or structural theories of war rape on the seeming premise that single sociocultural suggestions of causal factors should capture and explain all cases of wartime sexual violence at all times for them to be valid. Most social scientists emphasize precisely that the social reality is more complex than any one theoretical model can capture, thus he criticize the theories for not being something they never claimed to be. Similarly, Cockburn (2011) dismisses the rotten apple-narrative on the basis that it does not apply to all perpetrators. At their extremes, all three narratives suggest that perpetrators are deprived of agency, and thereby, implicitly, to some extent are victims, either of biology/genetics, limited mental capabilities or circumstances/social pressures. I have found no proponents that argue perpetrators are ever (fully) victims or (completely) void of agency or guilt. Rather than to renounce the possibly contributing explanatory powers or variables that these theoretical and epistemological leanings separately suggest, this brief presentation is intended to caution against the construction of singular, exclusive, sufficient, and generalizable theories. For instance, recent empirical studies within, e.g., the Democratic Republic of the Congo (DRC) document that for many soldiers who rape while on duty, it is precisely lust and sexual needs that motivate them - apparently invoking sociobiological argumentation and denouncing the much repeated claim that rape and sexual violence is never about sex (e.g., Baaz \& Stern, 2009; Elbert et al., 2013). In response to sociobiological explanations, Cockburn (2011) reminds her readers that sexuality and lust may also be socially constructed, a product of the mind rather than evolutionary biology. Thus, when Gottschall (2004) holds that the reproductive age of the majority of victims strongly suggests a biological reproductive drive, he ignores that this might also have its explanation in part or in whole in socially constructed processes. The point is, a theory need not cover or be applicable on all wars and cases for it to be valid or applicable under some conditions in particular contexts. No one theory or narrative about perpetrators and their rationales or motivations cover and explain all cases of sexual war violence. Whereas some perpetrators are likely to suffer pathological conditions, most do not. While some perpetrators are likely to sexually violate out of lust, many others seem to participate for non-sexual purposes. Whereas many perpetrators seem to have a distorted misogynist worldview based on institutional or societal conditioning and rape as a result, that is not a necessary precondition for all rape and sexual violence to take place. Complexity, nuances, and variability is key - not the simplicity that exclusive theoretical models argue.

\subsection{Disciplinary grounding: From qualitative feminist analyses to large-N statistics}


At the outset of research on sexualized war violence, it was primarily qualitatively oriented feminist researchers that engaged in the topic, as was also the case for sexual violence studies in general. Researchers openly shared a feminist orientation, political purpose and motivation: research efforts might help develop measures that better limit the prevalence of sexualized war violence and empower those subjected to it. Following the increased attention to sexual war violence within international politics ${ }^{10}$ and criminal prosecution ${ }^{11}$ and the recognition of sexual war violence as an important political and security issue, this field of research is gaining momentum outside its original, limited and ideologically grounded feminist constituency. This disciplinary mainstreaming results in a downplaying or abandoning of articulated feminist positioning among scholars and coincides with a shift from qualitative to quantitative methods. With the emergence of quantitative and comparative data analyses, several of the main theorizations prevalent in research on sexualized war violence based on qualitative case studies are challenged as assumptions. By the use of comparative conflict data and regression analyses, it is argued that not any one factor, such as gender inequality in peacetime, ethnically defined conflict lines, contraband funding, or genocidal warfare, can account for the prevalence of sexualized war violence(Cohen, 2013), or for the variation with which militaries commit sexualized violence (Wood, 2006).

In an article on the impact of globalization on criminology in 2012, Aas criticized the tendency of Western criminologists to make universal claims based on locally produced and

\footnotetext{
${ }^{10}$ As evident in four specifically targeted UN Security Council Resolutions on sexual war violence (UNSCR 1820 (2008), 1888 (2009), 1960 (2010) and 2106 (2013)), in addition to three general resolutions addressing challenges to women’s participation in peace and conflict arenas (UNSCR 1325 (2000), 1889 (2009) and 2122 (2013)), numerous conferences and international initiatives pertaining to sexual war violence specifically, and the establishment of a Special Representative of the Secretary-General (SRSG) on Sexual Violence in Conflict in 2010.

11 Prosecution of sexual war violence crimes is central to all UN mandated ad hoc international criminal tribunals as well as for the permanent International Criminal Court (ICC). In various forms it may constitute a Crime Against Humanity, Art 7 (1) (g), a War Crime, Art 8 (2) (b) (xii), (e), (vi), and Genocide, Art 6, in the ICC Rome Statute.
} 
situated knowledge. Drawing on Tsing (2011; see also Tsing, 2012) Aas warned against the ignorance to contextual factors that necessarily inform any general or universal criminological map that is based on zooming out from a contextually specific geo-, socio-, and political space. The criticism has its relevance also in this field. The flip side of the coin, however, is that we equally cannot easily project or zoom in from necessarily simplified statistics to complex social individuals and realities on the ground. Excluding suggested contributing processes and factors such as gender inequality on the basis of statistical compound evidence does not without qualification reflect the situation on the ground in individual wars, battles or armed groups, nor the variation of various factors' influences both between and within conflicts and individuals at different times. Noticeably, finding that gender inequality or masculinity norms are not statistically significant factors in a large- $\mathrm{N}$ set of conflicts or do not vary significantly between perpetrating and non-perpetrating groups, do not mean that male chauvinist attitudes or gender constructs are unimportant or irrelevant for understanding the justification and rationalization for sexualized war violence by members of perpetrating groups. Importantly, when Wood (2006) and Cohen (2013), who are prominent researchers in this field, hold theories of sexualized war violence at fault, they do so on the basis that the individual theories cannot account for the variation of all sexualized violence in all conflicts by all perpetrators at all times ${ }^{12}$.

In both qualitative and quantitative analyses of sexual war violence, there is a tendency to not elaborate on or emphasize that the empirical foundation of theorization is based on reported rape or sexual violence cases. A higher level of consistent accuracy is warranted, and it is important to recognize that there might be important differences between reported incidences of sexual violence and the universe of cases that is never reported. Given the high degree of stigma that is associated with sexual violence (Henry, 2011; Kaitesi, 2014; Leatherman, 2011; Sharratt, 2011; Sivakumaran, 2007), it is possible that victims who are not acutely in need of emergency medicine, or who were raped or sexually violated by single perpetrators, or without witnesses, choose to not report. As pointed out by Rubio-Marín (2012: 77), “[f]or many survivors, minimizing harm, rather than maximizing assistance and redress, will be the logical and existential priority after the conflict has subsided.” Others might not have access

\footnotetext{
${ }^{12}$ Wood explicitly states that this is a deliberate rhetorical assumption on her part to emphasize the importance of variation.
} 
to institutions or organizations to which they can report. There is also a potential risk that some might consider their experiences unworthy of reporting given the relative extremity of cases that are often publicly used to illustrate sexual war violence as a horrific weapon of $\operatorname{war}^{13}$.

\subsection{Contextual emphasis: From patriarchal continuum to war specific processes?}

Killing in war is legal under certain conditions, sexual violence never is, nor can it ever be an act of self-defense, the way killing arguably can. No wonder, then, that sexualized violence is approached as something separate, something substantially different from other forms of war violence in theorizations on this phenomenon. Skjelsbæk (2012a) has pointed out that a soldier who kills during war is likely not to have killed anyone prior to war and is likely never to kill in the aftermath of war. It is the specific war context that allows for, calls for and oftentimes - legitimizes the act of killing. Killing is seen as exceptional in the life course of the soldier, who is not likely to be considered a killer when he (or she) is done serving. Then Skjelsbæk replaces the soldier who killed with a soldier who raped or otherwise committed sexualized violence during war. Is it likely that he (or she) had not raped or sexually abused anyone prior to the war, would not have done so during war unless some very war specific processes and contexts allowed for or encouraged it, and even, that he or she would not do so again when the war ends?

In much literature on sexual war violence, these particular forms of violence are not seen as war specific in the same way that killing in war is. This continuum of violence-perspective on sexual violence puts contextual and explanatory emphasis on overall patriarchy and misogyny, and has been a particularly dominant perspective in publications on sexual war violence. According to the continuum-perspective, sexualized violence during conflict is primarily understood as a radicalization of the everyday violence and domination women are

\footnotetext{
${ }^{13}$ Although a somewhat anecdotal parallel, the lack of self-identification as a victim due to dramatic media and policy presentations of experiences associated with the term "victim" related to a particular category of crime, has been demonstrated in research focusing on victims of human trafficking (Brunovski \& Surtees, 2007). The extremity of the violence that illustrate media reporting on and political campaigns against sexual war violence has the potential of producing similar effects.
} 
subjected to in peacetime (e.g., Cockburn, 2004). Sexual violence is not seen as exceptional to war, although it is often considered exceptionally gruesome in relation to other repertoires of violence in wartime. As Maud Eduards' articulates it, war cannot be "separated from peacetime gender relations. The imperative is to seek an understanding of women's physical vulnerability in armed conflict in light of their subordinate position in society as such" (Eduards, 2004: 246, my translation). A consequence of this perspective is that sexual war violence is analyzed in isolation from other forms of violence that is perpetrated in the same war and conflict situations. For instance, in much reporting of sexual war violence, the killing of children and relatives in front of rape victims are mentioned only in passing before the rapes are dealt with in (often spectacular) detail as the horrible war experience. Another example from the literature base on sexual war violence that is often repeated is that of the socalled "rape of Nanking” during WWII. Many accounts of the massive sexual violence that was perpetrated by Japanese troops during the six weeks of the massacre that started in MidDecember 1937 fail to mention that most of the tens of thousands of women and children who were raped were also killed. Even more rare are these rapes and murders understood within the wider conflict situation where, within the same time frame of a few weeks, approximately 200,000 men were massacred (Skjelsbæk, 2010; Wood, 2006). It is striking how the sexual violence is almost consistently considered in isolation, as if a nonrelated and completely different phenomenon, or as if it is only sexual violence committed against the women victims that is gendered.

In contrast, Baaz and Stern (2010) have emphasized the importance of searching for causal explanations of sexualized war violence in studies of other forms of wartime violence, rather than seeing the phenomenon solely as an extension of generalized gender-based violence in society at large. Skjelsbæk’s example at the beginning of this section also reminds us of the importance of social processes, stress, pressure and chaos specific to the war context, no matter the violence committed or the gender of victims. The neglect of scholarship on sexual war violence to consider this violence as part of a wider repertoire of war violence, suggest another lacuna of research that scholars can engage in to possibly increase our understanding.

The portrayal of sexual war violence in general and wartime rape of women in particular as an exceptionally cruel crime, as the worst of war crimes, in much writings on the issue has perhaps been necessary to bring warranted attention to the phenomena captured by the 
aggregated term "sexual war violence” (e.g., Engle, 2005). It might also very well reflect the conviction of researchers that work closely with survivors. Rape and sexual violence is often associated with high levels of shame, social exclusion, taboos and is intimate and humiliating in ways that are rarely associated with other forms of violence, such as gun wounds, mutilation, forced displacement or conflict-induced poverty. Still, the often exclusive focus on sexual war violence and the construction of such a hierarchy of cruelty might also have unforeseen and negative consequences. In contest for attention towards a side of warfare that has been silenced for too long, other acts of violence and forms of suffering are neglected, both scholarly and politically. From a historical tendency where victims of rape and sexual violence were ignored and made invisible, we run the risk today of excluding people of severe and genuine needs through an exclusive focus on survivors of sexual war violence (Houge et al., 2015; Lemaitre and Sandvik, 2014). There are already examples of how the increased sensationalism surrounding sexual war violence, including exclusive earmarking of development projects and funds for survivors of sexual violence, leave victims suffering of non-sexual but gendered and war-related traumas, injuries and urgent needs, outside of social and medical services, unworthy of attention, empowerment and help (see more on this in Baaz \& Stern, 2013; Lake, 2014; Lemaitre \& Sandvik, 2014). ${ }^{14}$

\subsection{Policy implications: Security and criminalization from periphery to center}

How we theorize and conceptualize sexual war violence is important to recognize not only as a theoretical exercise, but because the ways in which we approach and understand sexual war violence affect how it is met socially and politically. Already mentioned is how the conceptual feminization of victimhood has the potential of leaving male victims out of empowerment and rehabilitation efforts directed at survivors of sexual war violence. Another aspect of this equation mark between women and victims is that women, qua women, are conceptualized as victims - when not all women are victims or survivors, nor is being raped or sexually abused necessarily or always a central or constant characteristic of those who are. In the rush towards granting overdue attention to women's war experiences and atrocities that women are often subjected to, there is a counter risk of depriving the women we re-present

\footnotetext{
${ }^{14}$ Note that this criticism does not in any way imply that the needs of victims of sexual violence are met. See references in supra note 3.
} 
and speak about of conceptual (and possibly, ultimately, material) agency (Engle, 2005, comments pointedly on this).

In only a few decades, policy-level attention to sexual war violence has shifted from nonexistent to central, from being considered a private matter to being addressed as a public and highly politicized one, and from being denoted as a consequence of warfare to a tactic, or a weapon, of war. With the 1990s' conceptualization of sexual violence in conflict situations as a weapon of war came a new form of political recognition, where not only feminists, but politicians and scholars more broadly, agreed that these crimes could never be accepted and were possible to prevent, resulting in increased international criminalization and prosecution of crimes within this category (see Askin, 1997; de Brouwer, 2005, for overviews of the history of international prosecution of sexual war violence). It has garnered massive attention in some conflicts followed by loud and insistent calls to fight impunity. Importantly, perpetrators are increasingly considered rational actors committing sexual violence with a political intent and for a military purpose - not as a result of biological drives (see Baaz \& Stern, 2013; Skjelsbæk, 2010).

This conceptual shift from considering sexual violence as an inevitable consequence of war to a weapon of war relies on research that is largely based on a few high profile cases, the wars in the former Yugoslavia and the genocide in Rwanda in the early 1990s. Although definitely spot on in some contexts, this widespread scholarly and, in particular, political belief or assumption of sexual war violence as a deliberate, strategic tool or weapon of war do not necessarily capture the complexities that explain sexual violence in many conflict situations (Crawford, 2013). The narrative about particularly rape, but also sexual violence, as a weapon of war, presupposes intentionality and a purpose larger than the act itself, as in Bosnia and Rwanda. Yet, the kind of planned top-down campaigns we witnessed in these particular settings are less frequent than the political slogan suggests, and rape or sexual violence need not be a deliberate weapon of war for it to be widespread. It can also be the result of a lack of military command structures, or as Cohen (2013)suggests, explicated by reference to group level measures to increase group cohesion and deter desertion. Pointing out that sexual war violence is not necessarily a deliberate weapon or tactic of war does not imply that the occurrence or offences are less grave or that they do not have effects that are potentially beneficial to warring parties. Thus, it is not an argument against prosecuting failure to 
prohibit or sanction widespread opportunist or competitive rape or sexual violence as practice within troops as a war or atrocity crime. Also, it need not be a weapon for it to be harmful and destabilizing for the victims subjected to it. What is important is that if we consider sexual war violence a weapon per se, presuming political intent, policy measures might not approach or address the phenomenon in constructive, preventive ways. Provided empirical studies from some areas and armed groups in the DRC that highlights individual soldiers' lust and opportunity, and Cohen's findings about sexual violence as a measure rather to build group cohesion on ground unit level, the weapon of war-paradigm does not seem to always fit well with the terrain it is used to describe (see Baaz \& Stern, 2013, for an elaborated critique). ${ }^{15}$

Another potential caution is related to the emergence and increased weighting of aggregated, statistical analyses. These analyses valuably add to, nuance and challenge generalized theories based on qualitative and narrative empirical analyses. Recent quantitative scholarship on the 129 identified active conflicts in the period from 1989-2009 worldwide, shows that out of the 625 identified armed actor groups involved in these conflicts, the percentage of state actors reported to be perpetrators of sexual violence is far higher (42 \%) than that of militias (17\%) and rebel groups (24\%) (Cohen and Nordås, 2014: 425). This challenges conventional wisdom that mostly holds unruly rebel groups to be primary perpetrators of sexual war violence (Cohen et al. 2013: 4). These are, to some extent, good news, as research on naming and shaming strategies suggest that these tactics have a better effect when directed against state leaders compared to those directed at insurgent groups (Krain, 2012). Yet, to the extent that statistical analyses replace one generalized theory with another, it might also trigger rigid policy responses that do not account for important situated variances and contextual specificities. To be sure, many militias and rebel groups also commit sexual war violence, and differentiated measures needs to be developed to reduce prevalence among those groups.

\section{Concluding remarks}

\footnotetext{
${ }^{15}$ Where Wood (2006) provides an overview of the variation in levels, forms of and possible explanations for sexual war violence between selected conflicts and different parties to these conflicts, Beevor’s (2002) narrative of the downfall of Berlin in 1945 offers an example of the variation with which sexual violence can be committed by soldiers from the same army within the same war (see also Dutton, 2007: 126-127; Lilly 2007).
} 
This review provides an overview of the proliferating research field that research on sexual war violence has become. The various publications and narratives on sexual war violence that I have addressed herein contribute to the analytical toolbox of theories on sexual war violence from different perspectives. The major achievements of feminist scholarship on sexual war violence, particular in terms of bringing attention to women's war experiences, instigating policy responses and advocating victim support and empowerment, should not be underestimated. Yet, I have primarily focused on (those parts of) publications that draw attention to other aspects of this research field than that of psychosocial and medical needs and consequences for survivors. This has been a deliberate choice to highlight critical theoretical differences and contestations. One of the central arguments that I make is to practice theoretical restraint - to be transparent and reflexive regarding theoretical claims and the complex social reality upon which they are made. Sexualized war violence is a complex phenomenon that requires a multi-factorial understanding where the weighting of each variable may differ both between conflicts and within, and, on an individual level, between perpetrating members of the same and different armed groups at different times. Whenever we attempt to reduce a complex social phenomenon to a one-dimensional and universal causal relationship, we will necessarily fail at some levels.

It has also been my purpose to introduce this field to internationally-oriented criminologists and scholars from adjacent fields and to point out research gaps that still need exploration. The weighting of a relatively few high profile cases for general theory construction has been mentioned and deserves critical attention. Another particularly interesting area is that of conditions, contexts and motivations, both on the level of individual soldiers and perpetrators and on the level of different groups and conflicts. If perpetrators are ordinary individuals under extraordinary circumstances - how is it that many soldiers do not become perpetrators of sexual war violence given the same situational pressures? At the conflict level, and given the high degree of variance in terms of how widespread sexual violence is in different conflicts, what social, institutional and political conditions are present in conflicts were sexual violence is not widespread vs those conflicts where sexual violence is? Following the specific criminalization of sexual violence at the international criminal tribunals and in the Rome Statute of the International Criminal Court, symbolic prosecution of selected perpetrators is celebrated as a key step in the ongoing fight against sexual war violence. Who is selected for prosecution, and who is not? How are these kinds of symbolic justice processes perceived in 
the war-torn communities in which the violence was committed? How is it that we re-present victims, bystanders and perpetrators in analyses, in court processes and in policies? How perpetrator-induced traumas are dealt with in post conflict societies - especially where perpetrators are not identified or prosecuted, is yet to be addressed. These are questions that criminologists are used to engage with in other areas and this article offers an outset from which scholars can also begin addressing these issues in this particular field. Sexual war violence - especially in light of recent years' international (symbolic) prosecution and criminalization processes and unison calls to fight impunity - warrants criminological attention.

\section{Acknowledgements}

I thank Inger Skjelsbæk, Kjersti Lohne, Thomas Ugelvik, Anne Bitsch, Liv Finstad and the editor as well as anonymous reviewers at AVB for their valuable comments on this article. I also thank members at the Gender, Peace and Security seminar course at the Peace Research Institute, Oslo (PRIO), in 2014, as well as participants at the Women and War seminar series hosted at the Department of Criminology and Sociology of Law, University of Oslo, fall 2013, where an earlier version of this article was presented.

\section{Funding}

This research received no specific grant from any funding agency in the public, commercial, or not-for-profit sectors.

\section{Bibliography}

Aas KF. (2012) 'The Earth is one but the world is not': Criminological theory and its geopolitical divisions. Theoretical Criminology 16 (1): 5-20.

Askin KD. (1997) War Crimes Against Women: Prosecution in International War Crimes Tribunals, Dordrecht: Martinus Nijhoff Publishers.

Baaz ME \& Stern M. (2009) Why Do Soldiers Rape? Masculinity, Violence, and Sexuality in the Armed Forces in the Congo (DRC). International Studies Quarterly 53 (2): 495518.

Baaz ME \& Stern M. (2010) The Complexity of Violence: A Critical Analysis of Sexual Violence in the Democratic Republic of Congo (DRC). Uppsala: Nordiska Afrikainstitutet, The Nordic Africa Institute. 
Baaz ME \& Stern M. (2013) Sexual Violence as a Weapon of War? Perceptions, Prescriptions, Problems in the Congo and Beyond, London: Zed Books.

Beevor A. (2002) Berlin: The Downfall 1945, London: Penguin Books.

Bosmans M. (2007) Challenges in Aid to Rape Victims: the Case of the Democratic Republic of the Congo. Essex Human Rights Review 4 (1): 1-12.

Brown SE. (2014) Female Perpetrators of the Rwandan Genocide. International Feminist Journal of Politics 16 (3): 448-469.

Brownmiller S. (1975) Against Our Will: Men, Women and Rape, New York: Bantam Books. Brunovskis A \& Surtees R. (2007) Leaving the Past Behind: Why Some Trafficking Victims Decline Assistance. Oslo: FAFO AIS.

Caldwell RA. (2012) Fallgirls. Gender and the Framing of Torture at Abu Ghraib, Farnham: Ashgate.

Carpenter C. (2007) Born of War: Protecting Children of Sexual Violence Survivors in Conflict Zones. Boulder: Lynne Rienner Publishers.

Carpenter RC. (2010) Forgetting Children Born of War. Setting the Human Rights Agenda in Bosnia and Beyond, New York: Columbia University Press.

Cockburn C. (2004) The Continuum of Violence. A Gender Perspective on War and Peace. In: Giles WM \& Hyndman J (eds) Sites of Violence. Gender and Conflict Zones. Berkeley: University of California Press, 24-44.

Cockburn C. (2011) 'Why Are You Doing This to Me?' Identity, Power and Sexual Violence in War. In: Jones KB, Bryson V \& Jónasdóttir AG (eds) Sexuality, Gender and Power. Intersectional and Transnational Perspectives. London: Routledge, 189-204.

Cohen DK. (2013) Explaining Rape during Civil War: Cross-National Evidence (1980-2009). American Political Science Review 107 (3): 461-477.

Cohen DK, Green AH \& Wood EJ. (2013) Wartime Sexual Violence. Misconceptions, Implications, and Ways Forward. Washington, D.C.,: United States Institute of Peace.

Cohen DK \& Nordås R. (2014) Sexual violence in armed conflict: Introducing the SVAC dataset, 1989-2009. Journal of Peace Research 51 (3): 418-428.

Cohen DK \& Nordås R. (n.a.) Sexual Violence in Armed Conflict Dataset (SVAC). Available at http://www.sexualviolencedata.org [last accessed June 2014]

Crawford KF. (2013) From spoils to weapons: framing wartime sexual violence. Gender \& Development 21 (3): 505-517. 
Dawes J. (2013) Evil Men, Cambridge: Harvard University Press.

de Brouwer A-M. (2005) Supranational Criminal Prosecution of Sexual Violence: the ICC and the Practice of the ICTY and the ICTR, Antwerpen ; Oxford: Intersentia.

de Brouwer A-M \& Ka Hon Chu S. (2009) The men who killed me. Rwandan survivors of sexual violence, Berkeley: Douglas and McIntyre.

Drumbl MA. (2000) Punishment Postgenocide: From Guilt to Shame to 'Civis' in Rwanda. New York University Law Review 75: 1221-1326.

Dutton DG. (2007) The Psychology of Genocide, Massacres, and extreme Violence. Why "Normal" People Come to Commit Atrocities, Westport: Praeger Security International.

Eduards M. (2004) Våld utan gränser: om krig och hotad manlighet [Violence Without Borders: on War and Threatened Manhood]. In: Svanström Y \& Östberg K (eds) Än män då? Kön och feminism i Sverige under 150 år [What about Men? 150 years of Gender and Feminism in Sweden] Stockholm: Atlas, 245-270.

Elbert T, Hinkel H, Mædl A, et al. (2013) Sexual and Gender-Based Violence in the Kivu Provinces of the Democratic Republic of Congo: Insights from Former Combatants. Washington, D.C.,: IBRD/World Bank.

Engle K. (2005) Feminism and Its (Dis)contents: Criminalizing Wartime Rape in Bosnia and Herzegovina. The American Journal of International Law 99 (4): 778-816.

Ericsson K. (2011) Rape, love and war-personal or political? Theoretical Criminology 15 (1): 67-82.

Fujii LA. (2009) Killing Neighbors. Webs of Violence in Rwanda, London: Cornell University Press.

Gertjejanssen WJ. (2004) Victims, Heroes, Survivors: Sexual Violence on the Eastern Front during World War II. University of Minnesota [PhD dissertation]

Gottschall J. (2004) Explaining Wartime Rape. Journal of Sex Research 41 (2): 129-136.

Grey R \& Shepherd LJ. (2013) “Stop Rape Now?”: Masculinity, Responsibility, and Conflictrelated Sexual Violence. Men and Masculinities 16 (1): 115-135.

Grossman D. (2009) On Killing: the Psychological Cost of Learning to Kill in War and Society, New York: Back Bay Books/Little, Brown and Co.

Hagan J, Rymond-Richmond W \& Parker P. (2005) The Criminology of Genocide: The Death and Rape of Darfur. Criminology 43 (3): 525-561. 
Henry N. (2010) The Impossibility of Bearing Witness: Wartime Rape and the Promise of Justice. Violence Against Women 16 (10): 1098-1119.

Henry N. (2011) War and rape: law, memory and justice, London: Routledge.

Henry N, Tony W \& Hirshberg M. (2004) A Multifactorial Model of Wartime Rape. Aggression and Violent Behavior 9 (5): 535-562.

Houge AB. (2008) Subversive Victims?: the (Non)Reporting of Sexual Violence Against Male Victims during the War in Bosnia-Herzegovina. Nordicom Review 29 (1): 63-78.

Houge AB. (2009) Seksualisert krigsvold i Bosnia og Hercegovina: kjønn, etnisitet og seksualitet [Sexualized War Violence in Bosnia and Herzegovina: Gender, Ethnicity and Sexuality]. Sosiologi i dag 39 (2): 23-42.

Houge AB. (2014) Sexualized War Violence: Subversive Victimization and Ignored Perpetrators. In: Lander I, Ravn S \& Jon N (eds) Control, Vulnerability and RiskTaking. Masculinities in the Criminological Field. Farnham: Ashgate, 165-183.

Houge AB, Lohne K \& Skilbrei M-L. (2015, forthcoming) Gender and crime revisited: criminological gender research on international and transnational crime and crime control. Journal of Scandinavian Studies in Criminology and Crime Prevention.

ICC. (2011) Elements of Crimes. The Hague: ICC.

Isikozlu E \& Millard AS. (2010) Towards a Typology of Wartime Rape. Bonn: Bonn International Center for Conversion, BICC.

Jolie A. (2014) Address to worldwide participants at the Global Summit to End Sexual Violence in Conflict. UK Foreign and Commonwealth Office, London, June 2014.

Jones A. (2006) Straight as a Rule: Heteronormativity, Gendercide, and the Noncombatant Male. Men and Masculinities 8 (4): 451-469.

Kaitesi U. (2014) Genocidal Gender and Sexual Violence: The legacy of the ICTR, Rwanda's ordinary courts and gacaca courts, Antwerpen: Intersentia.

Karstedt S. (2012) Contextualizing mass atrocity crimes: The dynamics of 'extremely violent societies'. European Journal of Criminology 9 (5): 499-513.

Kelman HC \& Hamilton VL. (1989) Crimes of Obedience, London: Yale University Press.

Kerry J \& Hague W. (2014, 25.02) Preventing Sexual Violence Is a National Security Imperative. The Huffington Post/The World Post.

Krain M. (2012) J'accuse! Does Naming and Shaming Perpetrators Reduce the Severity of Genocides or Politicides? International Studies Quarterly 56 (3): 574-589. 
Kuehnast K. (2014) Welcome and Introductory Remarks at Ending Sexual Violence in Conflict-seminar, Washington, D.C., United States Institute for Peace. Available from http://www.usip.org/events/ending-sexual-violence-in-conflict [last accessed June 2014]

Kuwert P, Klauer T, Eichhorn S, et al. (2010) Trauma and current posttraumatic stress symptoms in elderly German women who experienced wartime rapes in 1945. Journal of Nervous and Mental Disease 198 (6): 450-451.

Lake M. (2014) Organizing Hypocrisy: Providing Legal Accountability for Human Rights Violations in Areas of Limited Statehood. International Studies Quarterly 58 (3): 515526.

Leatherman J. (2011) Sexual violence and armed conflict, Cambridge: Polity Press.

Leiby ML. (2009) Wartime Sexual Violence in Guatemala and Peru. International Studies Quarterly 53 (2): 445-468.

Lemaitre J \& Sandvik K. (2014) Beyond Sexual Violence in Transitional Justice: Political Insecurity as a Gendered Harm. Feminist Legal Studies 22 (3): 243-261.

Leung R. (2004, 27 April) Abuse Of Iraqi POWs By GIs Probed. 60 Minutes, CBS News.

Lilly JR. (2007) Taken by Force. Rape and American GIs in Europe during World War II, New York: Palgrave.

Maier-Katkin D, Mears DP \& Bernard TJ. (2009) Towards a Criminology of Crimes Against Humanity. Theoretical Criminology 13 (2): 227-255.

Milgram S. (1974) Obedience to Authority: an Experimental View, New York,: Harper \& Row.

Milillo D. (2006) Rape as a Tactic of War: Social and Psychological Perspectives. Affilia 21 (2): 196-205.

Miller L. (2014) Rape: Sex crime, act of violence, or naturalistic adaptation? Aggression and Violent Behavior 19 (1): 67-81.

Mullins C. (2009a) “He Would Kill Me With His Penis”: Genocidal Rape in Rwanda as a State Crime. Critical Criminology 17 (1): 15-33.

Mullins CW. (2009b) 'We Are Going to Rape You and Taste Tutsi Women’: Rape during the 1994 Rwandan Genocide. British Journal of Criminology 49 (6): 719-735. 
Oosterveld V. (2011) The Gender Jurisprudence of the Special Court for Sierra Leone: Progress in the Revolutionary United Front Judgments. Cornell International Law Journal 44 (1): 49-74.

Peterman A, Cohen DK \& Palermo T. (2011) Rape Reporting During War. Why the numbers don't mean what you think they do. Foreign Affairs. Web only, available from http://www.foreignaffairs.com/articles/68008/amber-peterman-dara-kay-cohentia-palermo-and-amelia-hoover-gree/rape-reporting-during-war [last accessed June 2014]

Price LS. (2001) Finding the Man in the Soldier-Rapist: Some Reflections on Comprehension and Accountability. Womens Studies International Forum 24 (2): 211-227.

Rubio-Marín R. (2012) Reparations for Conflict-Related Sexual and Reproductive Violence: A Decalogue. William \& Mary Journal of Women and the Law 19 (1): 69-104.

Scheffer D. (2006) Genocide and Atrocity Crimes. Genocide Studies and Prevention 1 (3): 229-250.

Seifert R. (1994) War and rape: A preliminary analysis. In: Stiglmayer A (ed) Mass Rape: The war against women in Bosnia-Herzegovina. Lincoln: University of Nebraska Press, 54-72.

Sharratt S. (2011) Gender, Shame and Sexual Violence. The Voices of Witnesses and Court Members at War Crimes Tribunals, Farnham: Ashgate.

Sivakumaran S. (2007) Sexual Violence against Men in Armed Conflict. European Journal of International Law 18 (2): 253-276.

Sjoberg L. (2007) Agency, Militarized Femininity and Enemy Others: Observations From The War In Iraq. International Feminist Journal of Politics 9 (1): 82-101.

Skjelsbæk I. (2001) Sexual Violence and War: Mapping out a Complex Relationship. European Journal of International Relations 7 (2): 211-237.

Skjelsbæk I. (2010) The Elephant in the Room. An Overview of How Sexual Violence came to be Seen as a Weapon of War. Oslo: PRIO Peace Research Institute Oslo.

Skjelsbæk I. (2012a) Conceptualizing Sexual Violence Perpetrators in War. In: Bergsmo M, Skre, A. B. \& Wood, E. (ed) Understanding and Proving International Sex Crimes. TOAEP Torkel Opsahl Academic EPublisher, 495-509.

Skjelsbæk I. (2012b) The political psychology of war rape: studies from Bosnia and Herzegovina, London; New York: Routledge. 
Smeulers A. (2008) Perpetrators of International Crimes: Towards a Typology. In: Smeulers A \& Haveman R (eds) Supranational Criminology: Towards a Criminology of International Crimes. Antwerp, Oxford, Portland: Intersentia, 233-266.

Smeulers A \& Grünfeld F. (2011) International crimes and other gross human rights violations: A multi- and interdisciplinary textbook, Leiden: Martinus Nijhoff Publishers.

Smeulers A \& Haveman R. (2008) Supranational Criminology: Towards a Criminology of International Crimes. Antwerp: Intersentia.

Smeulers A \& Hoex L. (2010) Studying the Microdynamics of the Rwandan Genocide. British Journal of Criminology 50 (3): 435-454.

Stiglmayer A. (1994a) Mass Rape: the War Against Women in Bosnia-Herzegovina, Lincoln: University of Nebraska Press.

Stiglmayer A. (1994b) The Rapes in Bosnia-Herzegovina. In: Stiglmayer A (ed) Mass Rape: the War Against Women in Bosnia-Herzegovina. Lincoln: University of Nebraska Press.

Straus S. (2006) The Order of Genocide. Race, Power, and War in Rwanda, London: Cornell University Press.

Tanter R, Ball D \& van Klinken G. (2006) Masters of Terror. Indonesia's military and violence in East Timor. Oxford: Rowman and Littlefield Publishers, Inc.

Tsing AL. (2011) Don't trust that zoom button: The living world is not amenable to nested scales. Lecture at the Conceptualising the World conference. Oslo.

Tsing AL. (2012) On Nonscalability: The Living World Is Not Amenable to Precision-Nested Scales, Common Knowledge 18 (3): 505-524.

UN Security Council. (2000) Women and peace and security S/Res/1325 (2000).

UN Security Council. (2008) Women and peace and security S/Res/1820 (2008).

UN Security Council. (2009a) Women and peace and security. S/Res/1889 (2009).

UN Security Council. (2009b) Women and peace and security. S/Res/1888 (2009).

UN Security Council. (2010) Women and peace and security. S/Res/1960 (2010).

UN Security Council. (2013a) Women and peace and security. S/Res/2122 (2013).

UN Security Council. (2013b) Women and peace and security. S/Res/2160 (2013).

UN Security Council. (2014) Conflict-related sexual violence. UNSC S/2014/181. 
Vetlesen AJ. (2005) Evil and Human Agency. Understanding Collective Evildoing, Cambridge: Cambridge University Press.

Vietnam Veterans Against the War. (1971) Winter Soldier Investigation. Available at: http://www2.iath.virginia.edu/sixties/HTML_docs/Resources/Primary/Winter_Sold ier/WS_entry.html [last accessed June 2014]

Vranic S. (1996) Breaking the wall of silence: the voices of raped Bosnia, Zagreb: Izdanja Antibarbarus.

Weaver GM. (2010) Ideologies of Forgetting. Rape in the Vietnam War, New York: State University of New York.

Wood EJ. (2006) Variation in Sexual Violence during War. Politics \& Society 34 (3): 307342.

Wood EJ. (2009) Armed Groups and Sexual Violence: When Is Wartime Rape Rare? Politics \& Society 37 (1): 131-161.

Zarkov D. (2001) The Body of the Other Man: Sexual Violence and the Construction of Masculinity, Sexuality and Ethnicity in the Croatian Media. In: Moser CON \& Clark FC (eds) Victims, Perpetrators or Actors? Gender, armed conflict and political violence. London \& New York: Zed Books, 69-82.

Zimbardo PG. (2008) The Lucifer Effect: How Good People turn Evil, London: Rider. 